\title{
CUMPRIMENTO DA EXECUÇÃO DO RÉU A PARTIR DA SEGUNDA INSTÂNCIA: CONSTITUCIONALIDADE COMPARADA À IMPROBIDADE ADMINISTRATIVA
}

\section{Camila Mara de Albuquerque ${ }^{1}$ \\ Ilka Ramos ${ }^{2}$ \\ Maurício Martins Alves ${ }^{3}$}

\begin{abstract}
Resumo: O presente artigo busca verificar a constitucionalidade do cumprimento da condenação do réu, em matéria penal, após sentença em segunda instância. A metodologia utilizada baseia-se em artigos, doutrinas, jurisprudência e análise da decisão monocrática do Tribunal Pleno sobre o tema. Objetivou-se por examinar a partir da decomposição da narrativa e do julgamento do processo quanto a Improbidade Administrativa, a constitucionalidade do cumprimento de pena após segunda instância. Como resultado se obteve que por este julgamento se solidificou a compreensão de que o Supremo Tribunal Federal não vislumbra matéria de fato, somente de direito. A discussão proferida restou acerca do conflito entre os Princípios do Contraditório e Ampla Defesa por intermédio de recursos e o cumprimento da pena após segunda instância. Conclui-se que a decisão do STF no tocante ao início da pena é constitucional e correto, uma vez que todo o Devido Processo Legal é respeitado, bem como os demais princípios norteadores do Processo Penal.
\end{abstract}

Palavras-chave: Constitucionalidade; Cumprimento da condenação do réu após segunda instância; Lei 8.429/92; Improbidade Administrativa.

\footnotetext{
${ }^{1}$ Faculdade de Direito/UNIVAP, Brasil. E-mail: camila.m.albuquerque@hotmail.com.

2 Faculdade de Direito/UNIVAP, Brasil. E-mail: Ilka@univap.br.

3 Faculdade de Direito/UNIVAP, Brasil. E-mail: mmalves@univap.br.
} 